\title{
Development of E-Comic Learning Media on the Topic of the Human Digestive System
}

\author{
Ni Komang Restu Tri Krisnanti Udayani ${ }^{*}$, I Made Citra Wibawa ${ }^{2}$, Ni Wayan Rati ${ }^{3}$ \\ 1,2,3 Prodi Pendidikan Guru Sekolah Dasar, FIP, Universitas Pendidikan Ganesha, Singaraja, Indonesia \\ e-mail: krisnantirestu99@gmail.com
}

\section{A R T I C L E I N F O \\ Article history: \\ Received May 10, 2021 \\ Revised May 15, 2021 \\ Accepted July 24, 2021 \\ Available online August 25, 2021}

Kata Kunci:

Media, E-Comic, Sistem

Pencernaan

Keywords:

Media, E-Comic, Digestive

System

DOI:

http://dx.doi.org/10.23887/jet.v $5 \mathrm{i} 3.34732$

\begin{abstract}
A B S T R A K
Perubahan pembelajaran di masa pandemi membuat guru harus mampu mengubah pembelajaran yang biasanya dilaksanakan dengan tatap muka menjadi pembelajaran online yang tetap menyenangkan untuk siswa. Penggunaan media pembelajaran selama pembelajaran daring akan membantu guru dalam menyampaikan materi pembelajaran dengan lebih kreatif, sehingga pembelajaran menjadi lebih menyenangkan serta siswa mudah dalam memahami materi pembelajaran. Penelitian ini bertujuan untuk mengembangkan media pembelajaran e-comic pada topik sistem pencernaan manusia. Penelitian ini merupakan jenis penelitian pengembangan dengan menggunakan model ADDIE. Namun, tahap implementasi dan tahap evaluasi pada penelitian ini tidak dapat dilaksanakan karena pandemi COVID-19, keterbatasan waktu, sumber daya dan biaya. Sehingga, dalam penelitian ini hanya dilaksanakan tahap analisis, desain, serta pengembangan. Subjek pada penelitian ini adalah dua ahli media, dua ahli materi serta dua praktisi. Pengumpulan data dalam penelitian ini menggunakan metode kuesioner dengan melakukan analisis pada media pembelajaran e-comic. Data hasil validasi dari para ahli kemudian dianalisis menggunakan rumus mean untuk dapat mengetahui rata-rata skor validitas media pembelajaran e-comic pada topik sistem pencernaan manusia. Hasil analisis menunjukkan bahwa rata-rata skor validasi media pembelajaran e-comic pada topik sistem pencernaan manusia yaitu 4,65 dengan kualifikasi sangat baik dan validasi materi yaitu 4,57 dengan kualifikasi sangat baik. Jadi, media pembelajaran e-comic pada topik sistem pencernaan manusia dinyatakan valid dan memiliki kualifikasi sangat baik.
\end{abstract}

\section{A B S T R A C T}

Learning during a pandemic make teachers have to change learning that is usually carried out face-to-face into online learning that is still fun for students. Learning media during online learning will help teachers deliver learning material more creatively to become more enjoyable, and students easily understand the learning material. This study aims to develop ecomic learning media on the topic of the human digestive system. This research is a type of development research using the ADDIE model. However, this study's implementation and evaluation stages cannot be carried out due to the COVID-19 pandemic, limited time, resources, and costs. Thus, in this study, only the analysis, design, and development stages were carried out. The subjects in this study were two media experts, two material experts, and two practitioners. The data collected in this study used a questionnaire method by analyzing the e-comic learning media. The data from the validation results from the experts were then analyzed using the mean formula to find out the average validity score of e-comic learning media on the topic of the human digestive system. The analysis results show that the average validation score of e-comic learning media on the topic of the human digestive system is 4.65 with very good qualifications, and material validation is 4.57 with very good qualifications. So, e-comic learning media on the topic of the human digestive system are declared valid and have very good qualifications.

This is an open access article under the CC BY-SA license.

Copyright (C) 2021 by Author. Published by Universitas Pendidikan Ganesha.

\section{INTRODUCTION}

Coronavirus or Severe Acute Respiratory Syndrome Coronavirus 2 (SARS-CoV-2) is a virus that attacks the respiratory system (Hincal \& Alsaadi, 2021; Singhal, 2020). This disease due to viral infection is called COVID-19 (Baber, 2021; Guan et al., 2020; Jogezai et al., 2021; S. S. Shah et al., 2021). COVID-19 is a highly contagious disease that comes from the city of Wuhan in China, has become a pandemic and has spread worldwide (Hincal \& Alsaadi, 2021; Mishra et al., 2020; K. Shah et al., 2020). The COVID-19 pandemic has resulted in changes in all fields, one of which is education (Ghasem \& Ghannam, 2021). Despite this challenging 
situation, most academic institutions have made efforts to ensure the continuity of the learning process (Rafique et al., 2021). During the COVID-19 pandemic, the education system changed to a new learning method because face-to-face learning was stopped to minimize the spread of the virus (Azubuike et al., 2021). In response to prevent the inability of students to learn because the learning face to face is stopped, then the school has now switched to online learning (Jogezai et al., 2021). Online learning refers to the learning activities conducted through the Internet where teachers have to post teaching materials to the platform (Summak et al., 2010; Tang et al., 2021). Online learning media can be interpreted as media equipped with control devices that can be operated and access what users need, for example downloading resources for learning materials. The advantage of using online learning media is that learning is independent, can improve memory levels, provide a more learning experience, with text, audio, video and animation all used to convey information, and also make it easy to convey learning.

The readiness of teacher infrastructure during a pandemic, such as an internet access and learning media, requires more attention (Tang et al., 2021). Providing Student learning facilities such as learning media on online platforms is still a challenge for teachers (Hong et al., 2021). Media in learning is a tool for capturing, processing, and restructuring visual and verbal information. Media is a tool for delivering learning material. Interactive learning media can turn boring learning into fun learning (Maula \& Fatmawati, 2020). Media is considered good if the message or information in the media is conveyed following the message (Budiyono, 2020). Based on the distribution of questionnaires conducted in the fifth grade of SD Gugus IV, Kecamatan Buleleng found that some teachers did not use interesting learning media during online learning. The material in student books was still narrow due to the lack of explanations and supporting pictures, especially on the human digestive system. So that students do not have difficulties studying the human digestive system. The learning process on the human digestive system should use learning media that is attractive and easy to access by students online (Rahmata et al., 2020). If these problems are not resolved immediately, students will not understand the learning, and students will not be ready to learn.

The solution that has been done is to create e-comic learning media. The digital comic media used in science learning using Cartoon Story Maker software on the theme of always saving energy can increase the effectiveness of learning and have a significant effect on the learning process of fourth-grade students. Students' interest in learning can increase with digital comic media (Harmawati et al., 2020; Reis et al., 2021). The development of digital comic media shows that the development of digital comic media is needed especially to support social studies learning (Sukmanasa et al., 2017; Taufiq et al., 2020). The development of effective comic media as teaching materials can increase students' enthusiasm in learning so that it has an impact on student learning outcomes (Dwiasih \& Agung, 2021; Enteria \& Casumpang, 2019; Eva et al., 2020; Ntobuo et al., 2018). An e-comic is a series of pictures put into a box containing the entire story series (Hobri et al., 2019). Children, especially those at the elementary school level, generally like cartoon illustrations such as those presented in ecomics so that they will learn and feel entertained (Ntobuo et al., 2018). E-comic media is a form of graphic media that contains messages that teachers convey and is in the form of stories (Nugraheni, 2017). Images make the story easy to capture. The text makes e-comics easy to understand. The storyline makes the message or information you want to convey easy to follow and remember (Eva et al., 2020). For various purposes, e-comics can convey material on various sciences (Aggleton, 2019).

However, no media developed in this study has yet developed e-comic learning media on the human digestive system. So, through the development of e-comic learning media on the topic of the human digestive system, it is hoped that it can become an interesting and practical learning medium in helping children understand learning on the topic of the human digestive system. This research aims to develop e-comic learning media on the human digestive system and develop e-comic learning media on the topic of the human digestive system whose validity has been tested. With this research, it is hoped that it can help learn how the human digestive system can be carried out effectively and help teachers and students learn in various learning situations.

\section{METHOD}

This type of research design used in this study is a type of development research. Research on the development of e-comic learning media on the topic of the human digestive system uses the ADDIE research model (analysis, design, development, implementation, and evaluation). However, due to constraints such as the COVID-19 pandemic and limited time and financial research, the development of e-comic learning media on the topic of the human digestive system can only be carried out in 3 stages, the analysis, design, and development stages. The procedure for developing e-comic learning media goes through stages that refer to the ADDIE model. This study goes through three stages, analysis, design, and development stages. The ADDIE model chart applied in this study can be seen in Figure 1. 


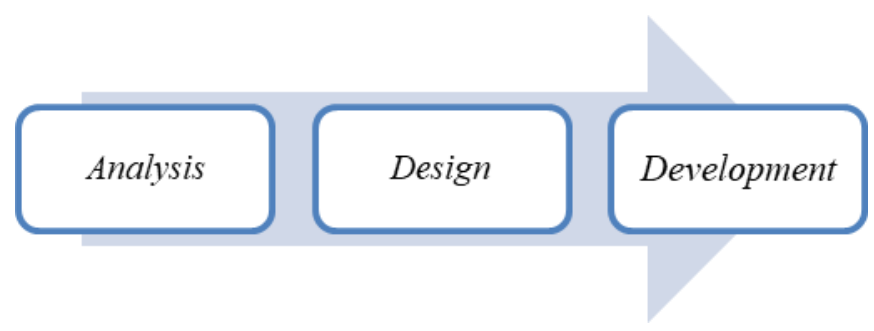

Figure 1. The ADDIE model

A needs analysis was carried out in the analysis stage by distributing questionnaires to fifth-grade teachers at SD Gugus IV, Kecamatan Buleleng. Analysis of student characteristics was carried out by analyzing the characteristics of fifth-grade elementary school students who were the target of the e-comic learning media developed in this study, analysis e-comic learning media by collecting information related to the criteria for good e-comic learning media, as well as curriculum analysis by analyzing Core Competencies, Basic Competencies, and indicators related to the human digestive system material. Several activities were carried out at the design stage: making a conversation script, designing a storyline, and giving colors. At the development stage, e-comic learning media development activities were carried out on the topic of the human digestive system, which had been consulted with the supervisor. After developing the e-comic learning media on the topic of the human digestive system, further trials were carried out on the e-comic learning media that had been developed. Through reviews from six experts, two media experts, two material experts, and two practitioners, product trials were carried out. After the experts have reviewed it, the experts will review the results. Furthermore, an analysis of the review results was conducted, and a revision was carried out on the e-comic learning media developed in this study.

The subjects in this study are two media experts, two material experts, and two practitioners who will assess the validity of the e-comic media developed. This study's object is the validity of e-comic learning media on the human digestive system. The types of data in this study were qualitative data and quantitative data. A questionnaire method was used to collect the data in this study. The instrument used to collect data in this research was in the form of a rating scale, which is data in the form of numbers interpreted to be descriptive. In this study, the rating scale assessment was in the form of an assessment sheet using a scale of 5-1. The instrument's validity was carried out through several stages: compiling the instrument grid, consulting the instrument grid with the supervisor, arranging the instruments, and assessing the judge's expert. The grid for the instrument validity sheet of e-comic learning media in this study consists of six aspects: visual aspects, visual aspects, typography, characterization, material, language, and integration presented in Table 1, Table 2, and Table 3.

Table 1. E-comic media expert validation instrument

\begin{tabular}{|c|c|c|}
\hline No & Aspect & Indicator \\
\hline 1 & Visual & $\begin{array}{l}\text { a. Media illustrations with learning materials are appropriate } \\
\text { b. Illustrations with student characteristics are correct } \\
\text { c. The background of the story is appropriate } \\
\text { d. The color with the characteristics of the students is appropriate } \\
\text { e. The color combination is harmonious }\end{array}$ \\
\hline 2 & Typography & $\begin{array}{l}\text { a. Selection of the type of text readability } \\
\text { b. Text size is correct } \\
\text { c. The text readability is correct }\end{array}$ \\
\hline 3 & Characteristics & $\begin{array}{l}\text { a. Figures with the student's character is appropriate } \\
\text { b. Interesting character design }\end{array}$ \\
\hline 4 & Presentation & $\begin{array}{l}\text { a. Interesting comic appearance } \\
\text { b. The proportions of the illustrations, characters, and word balloons are placed } \\
\text { correctly } \\
\text { c. The presentation of the material is clear }\end{array}$ \\
\hline
\end{tabular}

Table 2. Validation instruments for e-comic learning media by material experts

\begin{tabular}{cll}
\hline No & Aspect & \multicolumn{1}{c}{ Indicator } \\
\hline 1 & Material & a. The e-comic identity on the title page is complete \\
& & b. E-comics with appropriate learning materials
\end{tabular}




\begin{tabular}{|c|c|c|}
\hline No & Aspect & Indicator \\
\hline 2 & Language & $\begin{array}{l}\text { c. The material presented is easy to understand } \\
\text { d. The explanation according to the students' cognitive level is clear } \\
\text { a. Suitability of the language with the rules of the Indonesian language } \\
\text { b. The use of effective and efficient sentences is correct } \\
\text { c. The sentences used are easy to understand }\end{array}$ \\
\hline 3 & Presentation & $\begin{array}{l}\text { d. Use of punctuation and symbols are clear } \\
\text { a. Presentation of material is presented sequentially } \\
\text { b. Material with an integrated story }\end{array}$ \\
\hline
\end{tabular}

Table 3. Instrument validation for practitioner E-comic learning media

\begin{tabular}{|c|c|c|}
\hline No & Aspect & Indicator \\
\hline 1 & Visual & $\begin{array}{l}\text { a. Media illustrations with learning materials are appropriate } \\
\text { b. Illustrations with student characteristics are correct } \\
\text { c. The background of the story is appropriate } \\
\text { d. The color with the characteristics of the students is appropriate } \\
\text { e. The color combination is harmonious }\end{array}$ \\
\hline 2 & Typography & $\begin{array}{l}\text { a. Selection of text types that are easy to read } \\
\text { b. Text size is correct } \\
\text { c. The text readability is correct }\end{array}$ \\
\hline 3 & Characterization & $\begin{array}{l}\text { a. The character with the character of the student is appropriate } \\
\text { b. Interesting character design }\end{array}$ \\
\hline 4 & Presentation & $\begin{array}{l}\text { a. Interesting comic appearance } \\
\text { b. The proportions of the illustrations, characters, and word balloons are placed } \\
\text { correctly } \\
\text { c. The presentation of the material has a clear }\end{array}$ \\
\hline 5 & Material & $\begin{array}{l}\text { a. The e-comic identity on the title page is complete } \\
\text { b. E-comics with appropriate learning materials } \\
\text { c. The material presented is easy to understand } \\
\text { d. The explanation according to the students' cognitive level is clear }\end{array}$ \\
\hline 2 & Language & $\begin{array}{l}\text { a. Suitability of the language with the rules of the Indonesian language } \\
\text { b. The use of effective and efficient sentences is correct } \\
\text { c. The sentences used are easy to understand } \\
\text { d. Use of punctuation and symbols are clear }\end{array}$ \\
\hline 3 & Presentation & $\begin{array}{l}\text { a. Presentation of material is presented sequentially } \\
\text { b. Material with an integrated story }\end{array}$ \\
\hline
\end{tabular}

The grid of the e-comic learning media validation instrument was consulted with the supervisor. After carrying out the consultation, proceed with compiling instruments and ending with expert assessments (judges). Expert judgment was calculated using the Gregory formula to determine the content validity coefficient. The content validity of the e-comic learning media validation instrument on the topic of the human digestive system was 1.00 with all relevant instrument items. It is in the range of 0.80-1.00 with very high content validity criteria. This research's methods and data analysis techniques were qualitative descriptive analysis method and quantitative descriptive analysis. The data processed by the qualitative descriptive analysis method comes from criticism, input, and suggestions from the results of reviews by experts related to the media being developed. The quantitative descriptive analysis method was used to obtain the score of each expert through the expert assessment sheet. The score obtained calculated as the average to determine the validity of the media developed using the mean formula. The average score obtained converted using five scale conversion guidelines to determine the validity of the media being developed.

\section{RESULT AND DISCUSSION}

\section{Result}

The product produced in this development research is in the form of e-comic learning media on the fifth-grade human digestive system in elementary school for the 2020/2021 school year. This research on the development of e-comic media on the topic of the human digestive system was carried out using the ADIIE model. The ADIIE model consists of five stages: (1) analysis, (2) design, (3) development, (4) implementation, 
and (5) evaluation. (Isya', 2017). However, the implementation and evaluation stages were not carried out in this study due to the COVID-19 pandemic, time constraints, and costs.

The first stage is the analysis stage. At the analysis stage, the needs analysis activities, student characteristic analysis, curriculum analysis, and media analysis are carried out. The needs analysis was carried out by distributing questionnaires to fifth-grade teachers at SD Gugus IV, Buleleng District, about media use in learning and the need to develop e-comic learning media on the human digestive system. Based on the results of the questionnaire, it was found that $80 \%$ of teachers stated that the science content material in student books was still relatively low. $66.6 \%$ of teachers stated that they did not use interesting learning media during the online learning process. $66.6 \%$ of teachers stated that students were not enthusiastic about learning without using media learning. $100 \%$ of teachers stated that they had never used e-comic learning media. $66.6 \%$ of teachers stated that learning media on the topic of the human digestive system was difficult to find. $100 \%$ of teachers agreed that ecomic learning media were developed.

Analysis of student characteristics found that fifth-grade elementary school students were in the age 711 years in the concrete operational stage. Students would have difficulty learning at this stage without the help of objects that could explain the learning material. A curriculum analysis on the topic of the human digestive system for fifth-grade elementary school students is in Theme 3 on Healthy Food. Media analysis to develop ecomic learning media fulfills several criteria: media, typography, characterization, material, language, and integration. Visual aspects include suitability of illustrations, the accuracy of illustrations, suitability of backgrounds, suitability of colors, and harmony of colors. Typography aspects consist of choosing the type of text, the accuracy of the text size, and the legibility of the text. The characterization aspect consists of the suitability of the character's character and the attractiveness of the character's character design. The material aspect consists of completeness of identity, conformity with learning material, ease to understand, and clarity in providing explanations. The linguistic aspect consists of the suitability of the language with Indonesian rules, the use of effective and efficient sentences, the sentences used are easy to understand, and the use of clear punctuation and symbols. The aspect of coherence consists of having attractiveness, placing character illustrations and word balloons appropriately, a clear storyline, an ordered presentation of material, and the integration of the material with the story. Furthermore, the design stage is carried out.

At the design stage, the activities carried out were designing e-comic learning media based on media, typography, characterization, material, language, and integration. The design of e-comic learning media includes making conversation scripts, designing storylines, and giving colors. The e-comic learning media developed has a size of $21 \times 29.7 \mathrm{~cm}$ with 15 pages. The e-comic learning media developed in this study were divided into three parts, the opening, the content, and the closing. The opening part consists of a cover containing the media title and identity, basic competencies and indicators, and an introduction to the character. The content section consists of dialogues containing material about the human digestive system. The closing part consists of giving assignments. The storyline design is presented in Figure 1 and Figure 2.

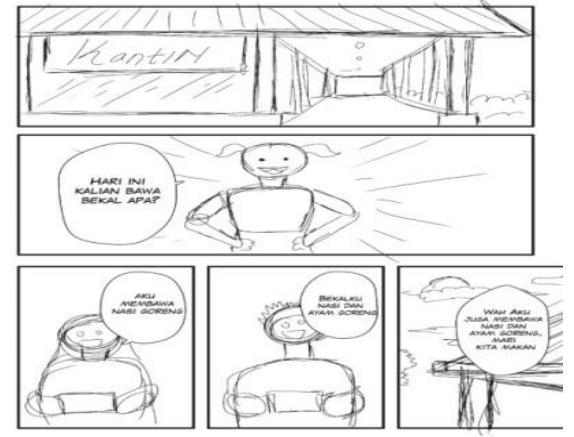

Figure 1. The design of the e-comic learning media storyline on the topic of the human digestive system

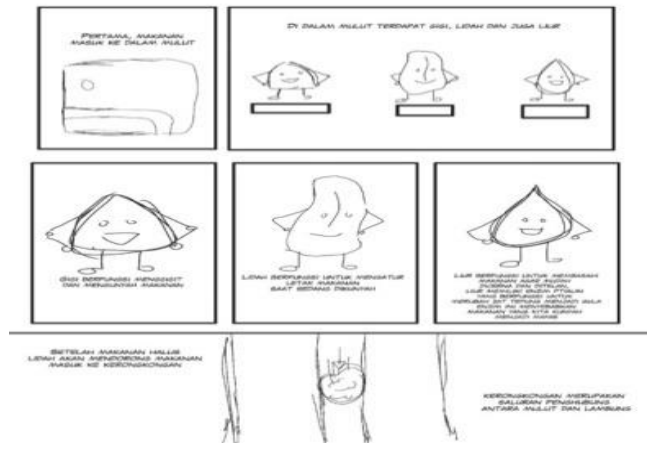

Figure 2. The design of the e-comic learning media storyline on the topic of the human digestive system

After the design was approved, then proceed to the development stage. In the development stage, the ecomic learning media was carried out according to the design and input from the supervisor. The developed ecomic learning media was divided into three parts: the opening, the content, and the closing part. The opening section consists of a cover containing the media title and identity, basic competencies and indicators, and an introduction to the character. The opening appearance of e-comics is presented in Figure 3. The content section consists of character dialogues about fifth-grade human digestive system learning materials. The appearance of 
the content of the e-comics is presented in Figure 4 and Figure 5. The closing section consists of giving assignments. The display of the closing section of the e-comic is presented in Figure 6 . If the e-comic learning media has passed the development process, it is continued with testing the validity of the experts. The validity test of e-comic learning media on the topic of the human digestive system is carried out online and offline by providing validity test sheets to two material experts, two media experts, and two practitioners.

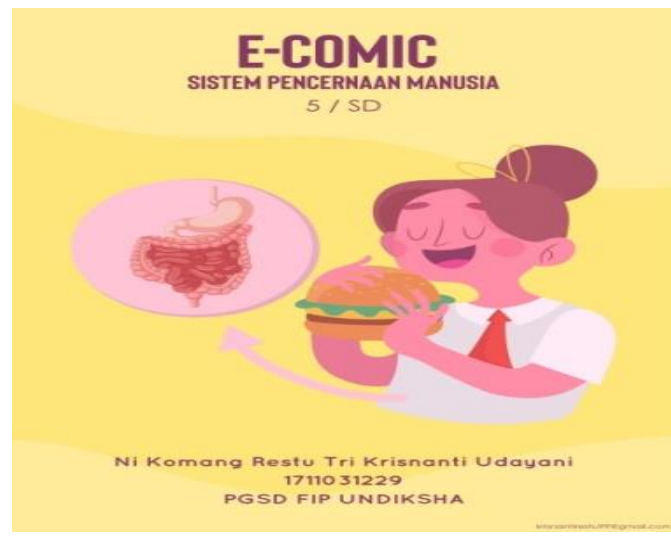

Figure 3. The opening section of e-comic learning media on the topic of the human digestive system
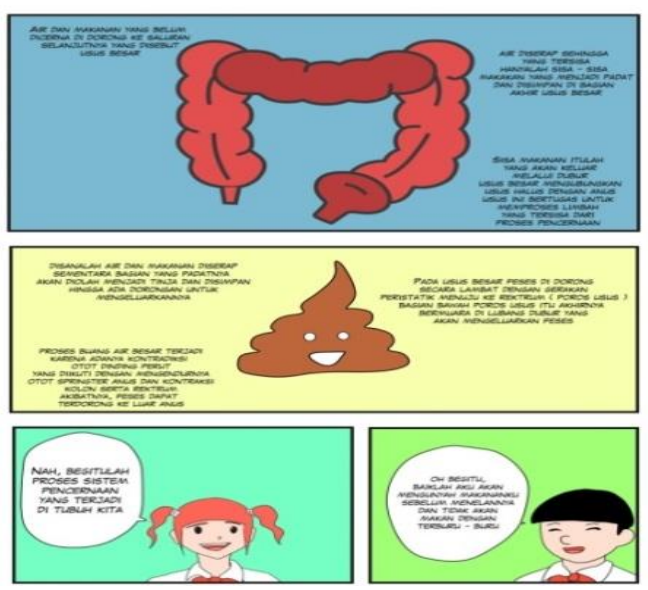

Figure 5. The content section of e-comic learning media on the topic of the human digestive system

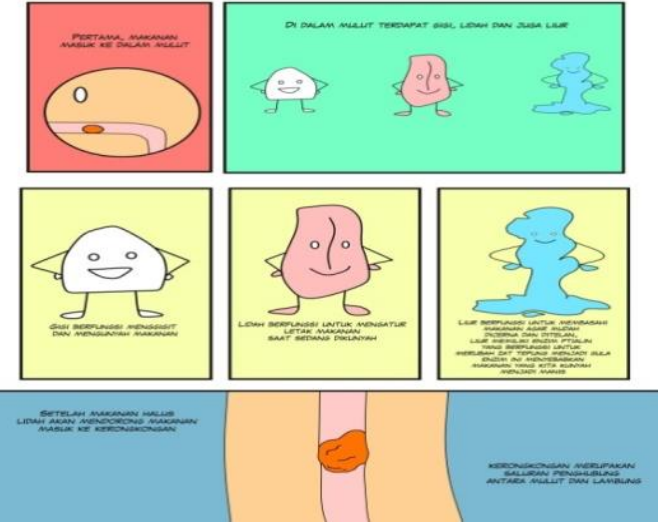

Figure 4. The content section of e-comic learning media on the topic of the human digestive system

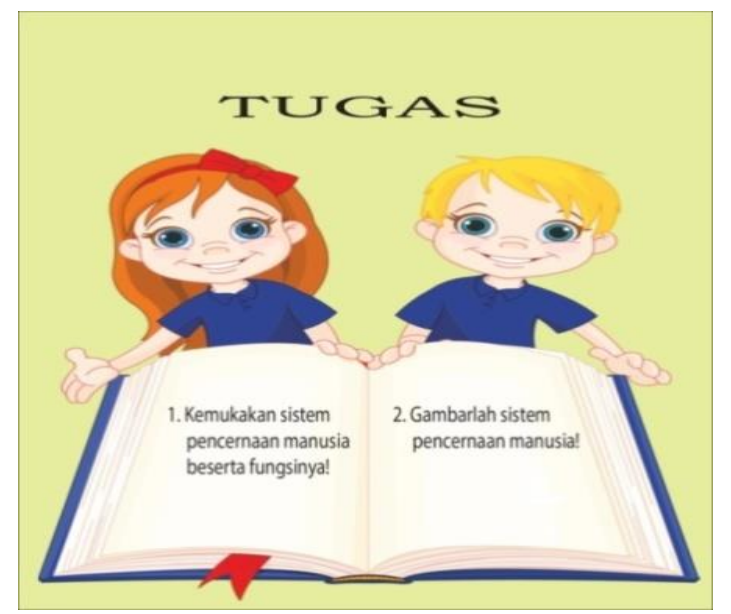

Figure 6. The closing section of e-comic learning media on the topic of the human digestive system

In the visual aspect, the E-comic learning media has an average of 4.65 with very good qualifications based on the scale of five conversion qualifications. So, the E-comic learning media developed in this study is suitable for use from a visual aspect. In the typography aspect, the E-comic learning media developed in this study received an average of 4.58 with very good qualifications based on the five-scale conversion qualification. So that the E-comic learning media developed in this study is suitable for use from the typography aspect. In the characterization aspect, the E-comic learning media developed in this study received an average of 4.37 with very good qualifications based on the five-scale conversion qualification. So that the E-comic learning media developed in this study is suitable for use from the characterizing aspect. In the material aspect, the E-comic learning media developed in this study received an average of 4.62 with very good qualifications based on the five-scale conversion qualification. So that the E-comic learning media developed in this study is suitable for use from the material aspect. In the linguistic aspect, the E-comic learning media in this study received an average of 4.5 with very good qualifications based on the five-scale conversion qualification. So that the E-comic learning media developed in this study is suitable for use from the linguistic aspect. In the integrated aspect, the E-comic learning media in this study received an average of 4.8 with very good qualifications based on the five-scale conversion qualification. So that the E-comic learning media developed in this study is suitable for use from an integrated aspect. Based on the results of the validity test, it was found that each instrument item got an average 
validity score of e-comic learning media, 4.65 with very good qualifications and material validity, 4.57 with very good qualifications in the range $3.75<\mathrm{X} \leq 5$. When carrying out the validity test of e-comic learning media, expert reviews are obtained. The results showed that the e-comic learning media developed in this study were valid/suitable for use.

\section{Discussion}

The visual aspect has illustrations that match fifth-grade elementary school students' characteristics, a harmonious blend of background and colors. The visual aspect can attract students interested in reading media and persist in reading the media content (Buchori et al., 2017; Koesoemadinata, 2018). Typographic aspects have the right type of text and text size, and readability of the text. The size of the letter greatly influences the readability of the text and the type of letter used because the smaller the letters used in e-comic media, the more blurry the font will appear, so that the legibility is less (Pattemore \& Muñoz, 2020; Thuneberg et al., 2018). The characterization aspect consists of the characters and the character designs of the characters that are interesting (Syahroni et al., 2016; Zhao \& Wu, 2021). In the e-comic learning media developed in this study, the characters match the students' character and the attractiveness of character designs. The material aspect consists of completeness of identity, conformity with learning material, ease to understand for elementary students, and clear explanations. The completeness and accuracy of the material developed in a learning media can make it easier for students to understand the intended learning material to achieve the learning objectives (Majid et al., 2012; Mayer, 2012; Purwanita et al., 2019). The linguistic aspect consists of the suitability of the language with Indonesian rules, the use of effective and efficient sentences, the sentences used are easy to understand and understand, and the use of clear punctuation and symbols. The use of appropriate sentences that students easily understand is very important in a learning medium. With this, students will easily understand the meaning of the material presented in the media (Alias \& Siraj, 2012; Linda et al., 2018; Neppala et al., 2018).The integration aspect has an appeal for elementary students, the placement of character illustrations and word balloons appropriately, a clear storyline, an ordered presentation of material, and the integration of the material with the story. Good integration must consider the ease of navigation and the aesthetics of each page so that students do not quickly feel bored reading the media (Yektyastuti \& Ikhsan, 2016).

The material in e-comic learning media on the topic of the human digestive system was following the child's development by using attractive illustrated pictures. E-comic learning media on the topic of the human digestive system were developed to help students learn with interesting learning media. So, even though learning was carried out online, students can still learn using learning media (Majid et al., 2012; Resita \& Ertikanto, 2018). The e-comic learning media has the advantage of being very easy to use because the form of presentation is simple. Looking at the pictures in the comics can give students creative ideas, and e-comics are more interesting and entertaining (Ntobuo et al., 2018; Yulianti et al., 2016). The e-comic learning media on the topic of the human digestive system was systematically designed to produce interesting and effective e-comic learning media for students. The e-comic learning media on the human digestive system developed in this study was different from the e-comic learning media previously developed because there are no e-comic learning media that develop the human digestive system. Technology-based media will make it easier for students to learn (Hendawi \& Nosair, 2020; Jang et al., 2021; Weng \& Chen, 2020). E-comic learning media can be accessed easily by students. The e-comic learning media developed in this study makes it easy for students to study anytime and anywhere. The e-comic learning media on the topic of the human digestive system developed in this study can be reached online and offline. Thus, the e-comic learning media on the human digestive system developed in this study can be used in various changing learning situations. The shortcomings of this e-comic media that it is only limited to the material of the human digestive system, and research was carried out only through three stages. The implementation and evaluation stages are not carried out because of the COVID-19 pandemic, time constraints, and costs. It is hoped that researchers conducting similar research can develop this research up to the implementation and evaluation stages.

Research result stated that using digital comics made using Cartoon Story Maker software can increase the effectiveness of learning on the subject matter of always saving energy (Riwanto \& Wulandari, 2018). Digital comic media could be developed and suitable for use (Hobri et al., 2019; Sukmanasa et al., 2017). The digital comic media is needed to be developed (Dwiasih \& Agung, 2021; Eva et al., 2020). It can be concluded that E-comic media can facilitate students in learning so that it impacts increasing student understanding. This research implies that the developed E-comic can be used by teachers in learning to help students in independent learning. 


\section{CONCLUSION}

The e-comic learning media on the human digestive system in this study were developed through validation and revision with very good qualifications. So, e-comic learning media is suitable for use. The trial was not carried out on students due to time, financial constraints, and the COVID-19 pandemic. So, it is suggested that other researchers carry out further research to determine the effectiveness of e-comic learning media in the field.

\section{REFERENCES}

Aggleton, J. (2019). Defining Digital Comics: a British Library Perspective. Journal of Graphic Novels and Comics, 10(4), 393-409. https://doi.org/10.1080/21504857.2018.1503189.

Alias, N., \& Siraj, S. (2012). Effectiveness of Isman Instructional Design Model in Developing Physics Module Based on Learning Style and Appropriate Technology. Procedia - Social and Behavioral Sciences, 64. https://doi.org/10.1016/j.sbspro.2012.11.002.

Azubuike, O. B., Adegboye, O., \& Quadri, H. (2021). Who Gets to Learn in a Pandemic? Exploring the Digital Divide in Remote Learning During the Covid-19 Pandemic in Nigeria. International Journal of Educational Research Open, 2-2. https://doi.org/10.1016/j.ijedro.2020.100022.

Baber, H. (2021). Modelling the Acceptance of E-Learning During the Pandemic of Covid-19: A Study of South Korea. The International Journal of Management Education, 19(2). https://doi.org/10.1016/j.ijme.2021.100503.

Buchori, Rahmawati, S., \& Wardani, S. (2017). The Development of A Learning Media for Visualizing the Pancasila Values Based on Information and Communication Technology. Jurnal Cakrawala Pendidikan, 36(3), 502-521. https://doi.org/10.21831/cp.v36i3.12748.

Budiyono, B. (2020). Inovasi Pemanfaatan Teknologi Sebagai Media Pembelajaran di Era Revolusi 4.0. Jurnal Kependidikan: Jurnal Hasil Penelitian aan Kajian Kepustakaan di Bidang Pendidikan, Pengajaran dan Pembelajaran, 6(2), 300. https://doi.org/10.33394/jk.v6i2.2475.

Dwiasih, A. A. I., \& Agung, A. A. G. (2021). The Development of Fabel E-Comic in Bahasa Indonesia Lesson for Grade II of Elementary School. Advances in Social Science, Education and Humanities Research. https://doi.org/10.2991/assehr.k.210407.284.

Enteria, O., \& Casumpang, P. F. H. (2019). Effectiveness of Developed Comic Strips as Intructional Materials in Teaching Specific Science Concepts. International Journal for Innovation Education and Research, 7(10), 876-882. https://doi.org/10.31686/ijier.vol7.iss10.1835.

Eva, R., Sumantri, M. S., \& Winarsih, M. (2020). Media Pembelajaran Abad 21: Komik Digital untuk Siswa Sekolah Dasar. Prosiding Seminar aan Diskusi Pendidikan Dasar. http://journal.unj.ac.id/unj/index.php/psdpd/article/view/17744.

Ghasem, N., \& Ghannam, M. (2021). Challenges, Benefits \& Amp; Drawbacks of Chemical Engineering Online Teaching During Covid-19 Pandemic. Education for Chemical Engineers, 36, 107-114. https://doi.org/10.1016/j.ece.2021.04.002.

Guan, W., Ni, Z., Hu, Y., Liang, W., Ou, C., He, J., Liu, L., Shan, H., Lei, C., Hui, D. S. C., Du, B., Li, L., Zeng, G., Yuen, K.-Y., Chen, R., Tang, C., Wang, T., Chen, P., Xiang, J., ... Zhong, N. (2020). Clinical Characteristics of Coronavirus Disease 2019 in China. New England Journal of Medicine, 382(18), 1708-1720. https://doi.org/10.1056/NEJMoa2002032.

Harmawati, D., Hasanah, N., Belwawin, S. M., \& Hidayat, S. H. (2020). Developing of an Educative Comic on the Theme of Clean and Healthy Life for Grade 2 Students of the Elementary Schools of YPPK Biankuk Merauke. Enfermería Clínica, 30(2). https://doi.org/10.1016/j.enfcli.2019.07.120.

Hendawi, M., \& Nosair, M. R. (2020). Students' Technological Awareness at the College of Education, Qatar University. Cypriot Journal of Educational Sciences, 15(4), 749-765. https://doi.org/10.18844/cjes.v15i4.5057.

Hincal, E., \& Alsaadi, S. H. (2021). Stability Analysis of Fractional Order Model on Corona Transmission Dynamics. Chaos, Solitons \& Fractals, 143, 110628. https://doi.org/10.1016/j.chaos.2020.110628.

Hobri, Murtikusuma, R. P., \& Hermawan, L. I. (2019). Development of E-Comic Using Pixton and Kelase Web on Linear Program of Two Variables Assisted by Geogebra. Journal of Physics: Conference Series, 1265, 012010. https://doi.org/10.1088/1742-6596/1265/1/012010.

Hong, J.-C., Lee, Y.-F., \& Ye, J.-H. (2021). Procrastination Predicts Online Self-Regulated Learning and Online Learning Ineffectiveness During the Coronavirus Lockdown. Personality and Individual Differences, 174, 110673. https://doi.org/10.1016/j.paid.2021.110673.

Isya', M. A. (2017). Pengembangan Model Pembelajaran Instruksional Design dengan Model ADDIE Mata Pelajaran PAI pada Materi Mengulang-ulang Hafalan Surah Al Ma'un dan Al Fil Secara Klasikal, 
Kelompok dan Individu Kelas V SDN Gedongan 2 Kota Mojokerto. Ta'dibia: Jurnal Ilmiah Pendidikan Agama Islam, 7(1), 71. https://doi.org/10.32616/tdb.v7.1.37.71-80.

Jang, M., Aavakare, M., Nikou, S., \& Kim, S. (2021). The Impact of Literacy on Intention to use Digital Technology for Learning: A Comparative Study of Korea and Finland. Telecommunications Policy, 45(7). https://doi.org/10.1016/j.telpol.2021.102154.

Jogezai, N. A., Baloch, F. A., Jaffar, M., Shah, T., Khilji, G. K., \& Bashir, S. (2021). Teachers' Attitudes Towards Social Media (SM) Use in Online Learning Amid the COVID-19 Pandemic: The Effects of SM Use by Teachers and Religious Scholars during Physical Distancing. Heliyon, 7(4). https://doi.org/10.1016/j.heliyon.2021.e06781.

Koesoemadinata, M. I. P. (2018). Visual Adaptation of Wayang Characters in Teguh Santosa's Comic Art. MUDRA: Jurnal Seni Budaya, 33(3). https://doi.org/10.31091/mudra.v33i3.544.

Linda, R., Herdini, Sulistya, I., \& Putra, T. P. (2018). Interactive E-Module Development through Chemistry Magazine on Kvisoft Flipbook Maker Application for Chemistry Learning in Second Semester at Second Grade Senior High School. Journal of Science Learning, 2(1), 21-25. https://doi.org/10.17509/jsl.v2i1.12933.

Majid, M. S. Z. B. A., Ali, M. M. B. A., Rahim, A. A. B. A., \& Khamis, N. Y. B. (2012). The Development of Technical English Multimedia Interactive Module to Enhance Student Centered Learning (SCL). Procedia - Social and Behavioral Sciences, 67, 345-348. https://doi.org/10.1016/j.sbspro.2012.11.337.

Maula, N. R., \& Fatmawati, L. (2020). Pengembangan Media Pembelajaran Kayaku (Kayanya Alam Negeriku) Berbasis STEM Kelas IV Sekolah Dasar. Jurnal Ilmiah Sekolah Dasar, 4(1), 97. https://doi.org/10.23887/jisd.v4i1.22351.

Mayer, R. E. (2012). A Cognitive Theory of Multimedia Learning. Multimedia Learning, July, 41-62. https://doi.org/10.1017/cbo9781139164603.004.

Mishra, L., Gupta, T., \& Shree, A. (2020). Online Teaching-Learning in Higher Education During Lockdown Period of Covid-19 Pandemic. International Journal of Educational Research Open, 1, 100012. https://doi.org/10.1016/j.ijedro.2020.100012.

Neppala, P., Sherer, M. V., Larson, G., Bryant, A. K., Panjwani, N., Murphy, J. D., \& Gillespie, E. F. (2018). An Interactive Contouring Module Improves Engagement and Interest in Radiation Oncology among Preclinical Medical Students: Results of a Randomized Trial. Practical Radiation Oncology, 8(4). https://doi.org/10.1016/j.prro.2018.01.001.

Ntobuo, N. E., Arbie, A., \& Amali, L. N. (2018). The Development of Gravity Comic Learning Media Based on Gorontalo Culture. Jurnal Pendidikan IPA Indonesia, 7(2), 246-251. https://doi.org/10.15294/jpii.v7i2.14344.

Pattemore, A., \& Muñoz, C. (2020). Learning L2 Constructions from Captioned Audio-Visual Exposure: The Effect of Learner-Related Factors. System, 93. https://doi.org/10.1016/j.system.2020.102303.

Purwanita, Y., Riyanto, Y., \& Suyanto, T. (2019). The Influence of Multimedia Assisted Inquiry Learning Methods on My Heroes Theme of Critical Thinking Skills and Learning Outcomes of Class IV Students ofElementary School. International Journal of Scientific and Research Publications (IJSRP), 9(7), p9169. https://doi.org/10.29322/ijsrp.9.07.2019.p9169.

Rafique, G. M., Mahmood, K., Warraich, N. F., \& Rehman, S. U. (2021). Readiness for Online Learning during COVID-19 pandemic: A survey of Pakistani LIS students. The Journal of Academic Librarianship, 47(3), 102346. https://doi.org/10.1016/j.acalib.2021.102346.

Rahmata, A., Tuljannah, L., Chotimah, S. C., \& Fiangga, S. (2020). Validitas E-Comic Matematika Berbasis Pemecahan Masalah pada Materi Kesebangunan. Jurnal Review Pembelajaran Matematika, 5(1), 5365. https://doi.org/10.15642/jrpm.2020.5.1.53-65.

Reis, F., Palermo, T. M., Acalantis, L., Nogueira, L. C., \& Meziat-Filho, N. (2021). "Journey to Learn About Pain": The Development and Validation of a Comic Book about Pain Neuroscience Education for Children. Brazilian Journal of Physical Therapy, 2. https://doi.org/10.1016/j.bjpt.2021.04.009.

Resita, I., \& Ertikanto, C. (2018). Designing Electronic Module Based on Learning Content Development System in Fostering Students' Multi Representation Skills. Journal of Physics: Conference Series, 1022(1), 012025. https://doi.org/10.1088/1742-6596/1022/1/012025.

Riwanto, M. A., \& Wulandari, M. P. (2018). Efektivitas Penggunaan Media Komik Digital (Cartoon Story Maker) dalam Pembelajaran Tema Selalu Berhemat Energi. Pancar, 2(1), 14-18. https://ejournal.unugha.ac.id/index.php/pancar/article/view/195.

Shah, K., Arfan, M., Mahariq, I., Ahmadian, A., Salahshour, S., \& Ferrara, M. (2020). Fractal-Fractional Mathematical Model Addressing the Situation of Corona Virus in Pakistan. Results in Physics, 19, 103560. https://doi.org/10.1016/j.rinp.2020.103560.

Revista de Psicodidáctica. https://doi.org/10.1016/j.psicod.2020.12.004.

Singhal, T. (2020). A Review of Coronavirus Disease 2019 (Covid-19). The Indian Journal of Pediatrics, 87(4), 
281-286. https://doi.org/10.1007/s12098-020-03263-6.

Sukmanasa, E., Windiyani, T., \& Novita, L. (2017). Pengembangan Media Pembelajaran Komik Digital pada Mata Pelajaran Ilmu Pengetahuan Sosial bagi Siswa Kelas V Sekolah Dasar di Kota Bogor. Jurnal Pendidikan Sekolah Dasar, 3(2), 171. https://doi.org/10.30870/jpsd.v3i2.2138.

Summak, M. S., Bağlıbel, M., \& Samancioğlu, M. (2010). Technology Readiness of Primary School Teachers: A Case Study in Turkey. Procedia-Social and Behavioral Sciences, 2(2), 2671-2675. https://doi.org/10.1016/j.sbspro.2010.03.393.

Syahroni, M. W., Dewi, N. R., \& Kasmui. (2016). The Effect of Using Digimon (Science Digital Module) with Scientific Approach at the Visualization of Students' Independence and Learning Results. Jurnal Pendidikan IPA Indonesia, 5(1), 116-122. https://doi.org/10.15294/jpii.v5i1.5800.

Tang, Y. M., Chen, P. C., Law, K. M. Y., Wu, C. H., Lau, Y., Guan, J., He, D., \& Ho, G. T. S. (2021). Comparative Analysis of Student's Live Online Learning Readiness During the Coronavirus (Covid-19) Pandemic in the Higher Education Sector. Computers \& Education, 168, 104211. https://doi.org/10.1016/j.compedu.2021.104211.

Taufiq, M., Wijayanti, A., \& Fajriah, E. (2020). The Implementation of E-Comic Earth Layer to Enhance Students' Self-Directed Learning. Journal of Physics: Conference Series, 1567, 022070. https://doi.org/10.1088/1742-6596/1567/2/022070.

Thuneberg, H. M., Salmi, H. S., \& Bogner, F. X. (2018). How Creativity, Autonomy and Visual Reasoning Contribute to Cognitive Learning in a STEAM Hands-On Inquiry-Based Math Module. Thinking Skills and Creativity, 29. https://doi.org/10.1016/j.tsc.2018.07.003.

Weng, S. S., \& Chen, H. C. (2020). Exploring the Role of Deep Learning Technology in the Sustainable Development of the Music Production Industry. Sustainability (Switzerland), 12(2), 1-20. https://doi.org/10.3390/su12020625.

Yektyastuti, R., \& Ikhsan, J. (2016). Pengembangan Media Pembelajaran Berbasis Android pada Materi Kelarutan untuk Meningkatkan Performa Akademik Siswa SMA. Jurnal Inovasi Pendidikan IPA, 2(1), 88. https://doi.org/10.21831/jipi.v2i1.10289.

Yulianti, D., Khanafiyah, S., \& Sulistyorini, S. (2016). Inquiry-Based Science Comic Physics Series Integrated with Character Education. Jurnal Pendidikan IPA Indonesia, 5(1), 38-44. https://doi.org/10.15294/jpii.v5i1.5787.

Zhao, Y., \& Wu, X. (2021). Impact of Visual Processing Skills on Reading Ability in Chinese Deaf Children. Research in Developmental Disabilities, 113. https://doi.org/10.1016/j.ridd.2021.103953. 